Article

\title{
Crude Oil Contaminated Sites: Evaluation by Using Risk Assessment Approach
}

\author{
Diana Mariana Cocârţă ${ }^{1, *}$, Mihaela Alexandra Stoian ${ }^{1}$ and Aykan Karademir ${ }^{2, *}$ \\ 1 Department of Energy Production and Use, Splaiul Independentei No. 313, Faculty of Power Engineering, \\ University POLITEHNICA of Bucharest, 006042 Bucharest, Romania; stoian_mihaela20@yahoo.com \\ 2 Department of Environmental Engineering, University of KOCAELI, Umuttepe Kampüsü, TR-41380 İzmit, \\ Kocaeli, Turkey \\ * Correspondence: aykan@kocaeli.edu.tr (A.K.); dmcocarta@gmail.com (D.M.C.); Tel.: +90-262-303-3192 (A.K.)
}

Received: 9 July 2017; Accepted: 27 July 2017; Published: 3 August 2017

\begin{abstract}
Soils contaminated with toxic and persistent pollutants pose different and serious hazards to the environment and human health. Multidisciplinary procedures that are considering models for the prediction of risk for long-term exposure are needed. The present paper illustrates the operating mode and utility of an environmental software able toe 0 ) integrates the dose-response modeling as a major part of hazard characterization in order to assess the quantitative risk from carcinogens. In this way, risk assessment is used as a method for the investigation of contaminated sites. The method is demonstrated on a Romanian field site, contaminated with petroleum products. For the assessment of human health risks from oil-contaminated sites, the contaminants of concern are considered as polycyclic aromatic hydrocarbons (PAHs), monocyclic aromatic hydrocarbons (MAHs), and heavy metals, chemicals known as human carcinogens. Quantitative risk calculations revealed an individual risk of $1.07 \times 10^{-5}$ for children and $6.89 \times 10^{-6}$ for adults. The paper represents a utility example of an environmental software solution that could be considered by decision-making factors in approving certain projects. The software tool is helpful for protecting the environment and human health.
\end{abstract}

Keywords: exposure modeling; heavy metals; hydrocarbons; risk assessment; soil pollution

\section{Introduction}

Soil pollution can be generated by the presence of human-made chemicals or other changes in the natural soil environment. Specifically, this could be caused by industrial activities, agricultural chemicals, or inappropriate disposal of waste [1-5]. According to European Environmental Agency (EEA) studies on the basis of non-harmonized national inventories, there are 2.5 million potentially contaminated sites in Europe (EEA-33 plus the six cooperating countries). About one third (an estimated total of 342,000 contaminated sites) have already been identified and about $15 \%$ of these have been remediated [6]. Soil contamination, most frequently with heavy metals and petroleum products, is a widespread problem in Europe [7]. Consequently, pollution caused by petroleum products is one of the most common problems in the environment [8-12].

The assessment of health hazards produced by oil exploration and exploitation is an important environmental issue in order to ensure the wellbeing of people. The lack of information concerning the quantification of the exposure to soil contaminants made necessary the development of environmental tools with particular interest for decision-makers and researchers. The source-pathway-receptor is a wide-spread concept in human health risk assessment of contaminated sites [13-19]. There are different methodologies for assessing the impact of anthropogenic pollution on a given site [20-23]. Thus, specific literature shows that, in order to manage the contaminated sites based on the protection of receptors and the environment, each country developed its own system. In Romania, the risk 
assessment approach related to the contaminated sites was first truly evidenced in the National Strategy for the Management of Contaminated Sites [24]. The national strategy is characterized through an approach based on risk analysis in managing soil and groundwater contamination and identification of adverse effects (human or environmental health) or potential migration of pollutants. Thereafter, appropriate measures are established in order to mitigate the assessed risk, so as to achieve acceptable risk: "Risk-Based Land Management" (RBLM). Although there are general remediation techniques for certain types of pollutants, specific decontamination methods to be applied always depend on the site characteristics. The remediation method chosen depends not only on the pollutant type, the source-path-receiver connection, but also the geological conditions and receptors located in both the polluted region and background divisions. According to the methodology presented in the strategy, the selection of the remediation technique is based on the risk assessment and analysis of remedial options.

The research work illustrated in the present paper is an integral part of a Romanian project co-financed by the European Regional Development Fund called RECOLAND. The main aim of this paper is to present the operating mode and utility of an environmental software solution able to help decision-makers respond to soil contamination problems. In this way, it could be possible to identify the most appropriate approach that should be used in approving certain solutions for the management of contaminated sites taking into consideration the potential impact on human health.

\section{Materials and Methods}

The case study in the current paper is focused on soil pollution with crude oil. Particularly, groups of chemical contaminants, including polycyclic aromatic hydrocarbons (PAHs), monocyclic aromatic hydrocarbons (MAHs), and heavy metals were considered. This choice is motivated by the fact that concerning contamination with petroleum products, contaminants of concern are Total Petroleum Hydrocarbons (TPH), Polycyclic Aromatic Hydrocarbons (PAHs), and Volatile Organic Compounds (VOCs) (for example benzene, ethylbenzene, toluene, and xylene (BTEX)) due to their toxic properties and negative effects on human health [25]. On the other hand, soil pollution with petroleum products is one of the main sources of soil contamination [26]. As soil has become an important environmental recipient for PAHs, in the framework of the present study, 16 PAHs considered as priority pollutants by the Agency for Toxic Substances and Disease Registry (ATSDR) [27] are taken into account. Eleven of them have been classified as probable/ possible human carcinogens by the US EPA (2015), while the International Agency for Research on Cancer (IARC) [28] considered them for the assessment of cancer risk from contaminated sites with PAHs. Concerning MAHs, in accordance with US EPA, the human health risk was assessed for two of BTEX: benzene $\left(\mathrm{C}_{6} \mathrm{H}_{6}\right)$ and ethylbenzene $\left(\mathrm{C}_{8} \mathrm{H}_{10}\right)$. The carcinogenic risk was estimated for five heavy metals (arsenic, cadmium, hexavalent chromium, nickel, and lead) which are considered probable/possible human carcinogens by the US EPA and Health Canada [29].

The investigated soil in the present study comes from an industrial area in Romania. Pollution arose due to the petroleum industry located nearby and soil contamination occurred through oil spills. Eight volumes of soil were sampled at a depth of $0-20 \mathrm{~cm}$ from an area of $1000 \mathrm{~m}^{2}$. The content of all contaminants were determined for every single soil sample. Thus, in order to characterize the soil, analytical tests were performed.

With the aim of identifying the concentration levels for PAHs, the analytical procedure was performed according the current standard methods in force: SR ISO 13877:1999 [30]. The solid samples were passed through a sieve of approximately $2 \mathrm{~mm}$ openings in width. Concerning the organic contamination, six Soxhlet extractors were used for sample extraction (model Gerhardt classic Soxhlet apparatus, Gerhardt (Germany)). An approximate $20 \mathrm{~g}$ portion of contaminated soil was extracted with $250 \mathrm{~mL}$ of high-performance liquid chromatography (HPLC) (model Shimadzu-UFLC-10A, Shimadzu (China))-grade petroleum ether solvent. The extract was concentrated to a low solvent volume using a Heidolph rotary evaporator (model Heidolph Hei-VAP, Heidolph (Germany)) and eluted with hexane. 
After the concentration step samples were cleaned up, if necessary, or were transferred to a capped and sealed vial for gas-chromatographic analysis [31,32].

MAHs were identified using the current standard methods, ISO 22155:2011 [33] and EPA 8260B:1996 [34]. The analytical procedure to measure the heavy metal concentrations was performed according to standard methods in force: SR ISO 11047:1999 [35] and ISO 20280:2007 [36]. The equipment used to determine the concentration of contaminants of concern investigated in this paper included a CINTRA 6 spectrophotometer, an AAS Analyst 800 spectrometer with a flame system and graphite furnace, a FIAS TRACE Ultra gas chromatograph with a flame ionization detector (FID), an Agilent 1200 HPLC with fluorescence detection and a diode-array, a FOCUS-PolarisQ gas chromatograph/mass spectrometer and an ICS-3000 ion chromatograph.

\subsection{Human Exposure Modelling and Risk Assessment Methodology}

Human health risk assessment developed in the framework of the present study is related to contaminated site risk assessment. Some different methods were developed for the assessment of risks from soil pollution after 1980s, such as HRS (hazard ranking system) Method (by the US EPA in 1980), the National Classification System for Contaminated Sites (by the Canadian Council of Ministers of the Environment in 1992), the Baden-Württemberg Method (in 1983), and others [37,38]. Examples of environmental tools using these kinds of models to determine risks to human health are the ASTM Risk-Based Corrective Action (RBCA), CSOIL, CLEA (Contaminated Land Exposure Assessment), and others [39]. Generally, results of human health risk assessment of contaminated sites are used to identify the optimal solution for soil remediation [40].

Concerning soil pollution, human health can be affected through ingestion [7], inhalation [41], or dermal contact [42] with contaminated dust and soil, water, or contaminated air. With regard to human health risk assessment, the EPA established the main steps included in the assessment methods and models in the 1980s. Using these methods and models it can be evaluated if the estimated risk from contaminated sites is an acceptable one or not. It is already known that an acceptable individual risk is $10^{-6}$, as suggested by World Health Organization, means that one case of cancer out of one million exposed people is considered acceptable [43].

Human health risk assessment is accomplished in three steps: exposure assessment, toxicity assessment, and risk characterization. The exposure assessment involves the determination of the exposure magnitude, the identification of an exposed or potentially exposed population, and the estimation of frequency and duration of exposure. The most important level of the exposure assessment is to identify human exposure pathways. Toxicity assessment contains hazard identification and dose-response assessment. The last step in human risk assessment is characterization of risk, which is supposed to estimate the non-cancer hazard and cancer risk $[40,44]$. Non-cancer or cancer risk depends on contaminant dose. Contamination can produce local effects (organs, direct contact zones) or it can affect the entire system (respiratory system, nervous system, etc.). The main organs affected throughout the exposure to a contaminated site through multiple exposure pathways are: lungs, skin, kidneys, and liver [40].

\section{2. "RECOLAND v1.0" Software Tool for Risk Analysis}

An important particularity characterizing the results concerning risk assessment is the fact that risk information is often illustrated by a single value for an entire investigated area. In this way, the user has no information with regard to the spatial variation of the evaluated risks within the region. As a result, especially for the soil contamination affecting important areas, decision-makers would not have complete and detailed information when choosing remediation solutions for the management of contaminated sites. This could take place because of two main reasons: a limited number of active monitoring units (sampling points) in the investigated areas and the lack of some appropriate instruments for the risk assessment. 
Development of the "RECOLAND v1.0" (University POLITEHNICA of Bucharest, Romania) software tool for risk analysis aimed at overcoming these issues. It is a software tool able to perform, in a fast and accurate way, the assessment of human health risks from contaminated sites. The software was realized in the framework of research developed within a European project in order to obtain a correct and comprehensive exposure assessment. In addition to assessing risks, it presents a multi-criteria decision support system able to provide support in choosing the optimum technology for decontamination of polluted soils while taking into account efficient technologies, risks for the exposed population, and associated decontamination costs. "RECOLAND v1.0" was developed across the RECOLAND project (POSCCE-A2-O2.1.2.-2009-2 ctr. no 182/18.06.2010).

"RECOLAND v1.0" could run on any computer with Windows XP (all versions), Windows Vista (all versions), Windows 7 (all versions), and Windows 8 (all versions) operating systems, both 32-bit and 64-bit. The computer must have greater than 512 MB RAM and at least 1 GB of free hard-disk space. The programming language is C\#. Based on pollutant concentrations identified in the soil "RECOLAND v1.0" is able to evaluate the degree of contamination of a soil taking into account the thresholds for different contaminants' concentrations in soil stipulated by the national Ministerial Order 756/1997 in force [45]. It can be used to estimate doses and to evaluate if the exposure to the contaminated site can induce carcinogenic risk for the exposed population through multiple exposure routes. The RECOLAND model is similar to other models developed in different countries, such as CSOIL in The Netherlands [46], following the model developed by the US EPA, while considering the specific habits of consumption for the exposed population. The considered equations from the EPA model are given in details in the US EPA-Risk Assessment Guidance for Superfund: Volume I-Human Health Evaluation Manual, published for the first time in 1989 [47,48].

Facilities mentioned before lead to the use of risk-based practices for the management of the contaminated sites by the environmental specialists. This allows managers to know sooner (for instance, before using one remediation technology or another) which solution should receive the most attention and funding in order to solve the environmental challenge, being well-known that soil pollution exposure is a global environmental management concern. In such a way "RECOLAND v1.0" brings a powerful technique for selecting cost-effective and environmentally-preferable solutions for the remediation of contaminated sites ensuring, at the same time, minimum risks for human health. The software tool was designed to help the environmental professional, as an environmental decision support system. The main components of the environmental tool related to the human health risk component of the software are illustrated in Figure 1.

The present study shows the main results achieved by using the RECOLAND software when human health risk from contaminated site with crude oil is assessed. Particularly, representative pollutants from different groups of contaminants that are known to be carcinogenic for human health were taken into consideration in a soil pollution case due to an oil spill. The general approach considered in the framework of the scientific work is schematically presented in Figure 2. 
1) Concentration of the contaminants in soil

2) GPS coordinates for every single sampling point and for defining the sampling area

3) Formulation of the land use scenario (residential, commercial or industrial land uses)

4) Information on parameters that are changing together with the pollutant type

5) Information on parameters that are changing together with area particularities
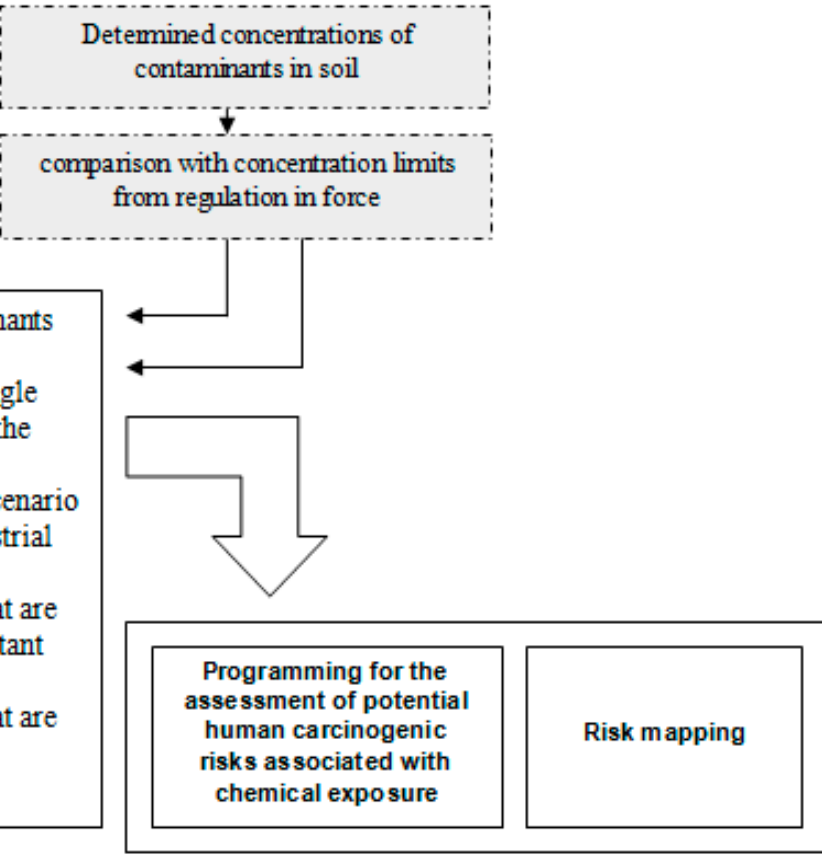

Output Data

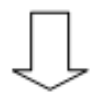

1) Report on soil overhangs

2) Graphical representation of concentrations in soil higher

than the maximum concentration limits

3) Illustration of the results from the assessment of multiple exposure to chemical elements

4) Graphical representation of chemical risks on risk maps

5) Maximum individual risk in the investigated area

Figure 1. Structure of the Human Health Risk Assessment Module included in the RECOLAND software.

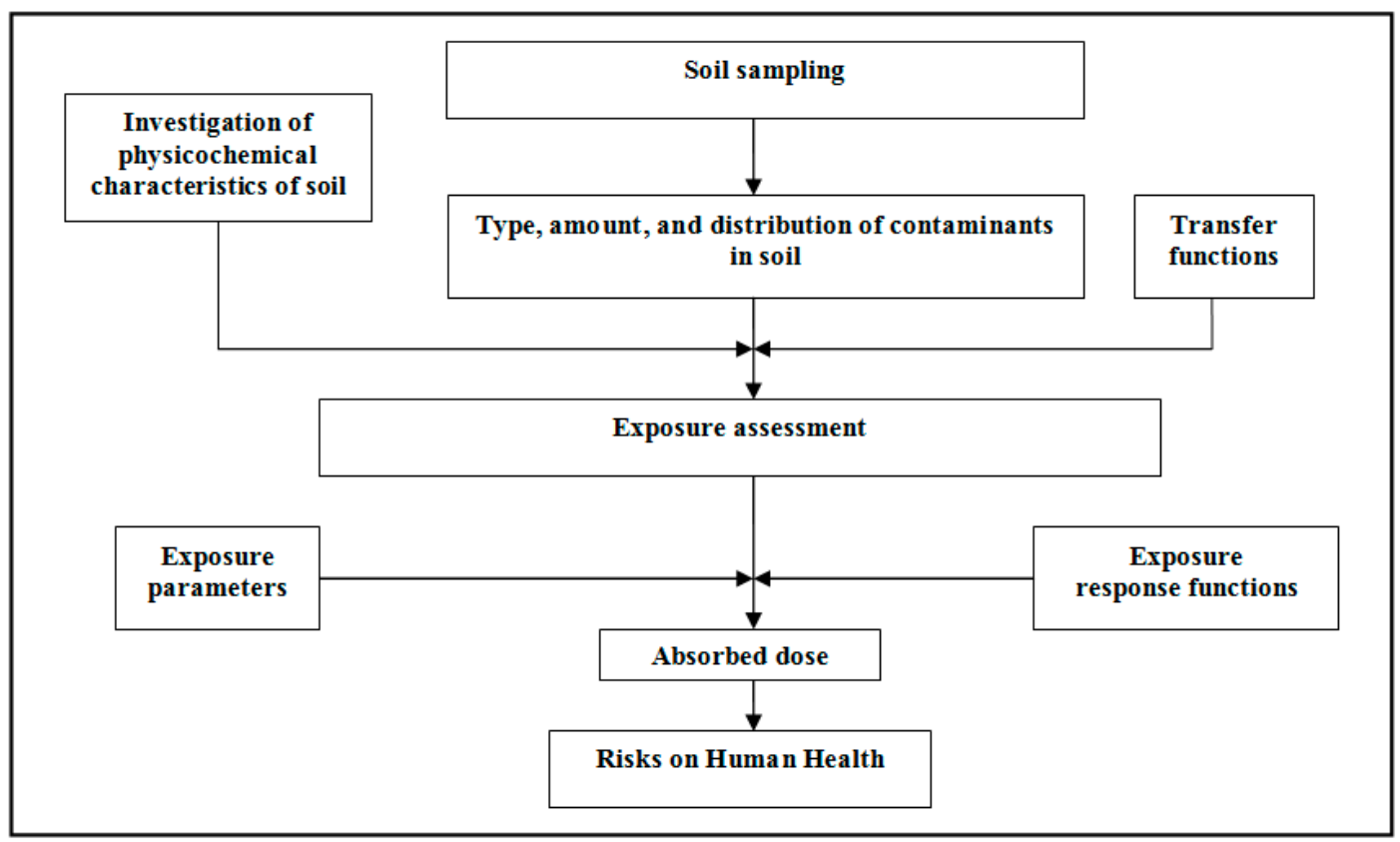

Figure 2. The general approach in the framework of the research study. 


\section{Results and Discussion}

\subsection{PAHs, MAHs, and Heavy Metal Concentrations in Soil}

In the framework of the research work, the concentration level for sixteen individual PAHs, four MAHs, and eleven heavy metals were determined in the soil samples from the investigated area. As mentioned before, the results were evaluated based on the thresholds established by the Romanian regulations on the assessment of environmental pollution (Table 1) [45]. The Ministerial Order 756/1997 establishes the alert and intervention thresholds concentrations of pollutants in soils, in correlation with the specific purpose of land use (recreational land use).

Table 1. Thresholds in the soil established by the Romanian regulations (mg/kg dry weight) [45].

\begin{tabular}{|c|c|c|}
\hline \multirow[t]{2}{*}{ Contaminant } & $\begin{array}{c}\text { Alert Threshold } \\
\text { Depending on Land Use }\end{array}$ & $\begin{array}{l}\text { Intervention Threshold } \\
\text { Depending on Land Use }\end{array}$ \\
\hline & Less Sensitive Land Use & Less Sensitive Land Use \\
\hline Benzene & 0.5 & 2 \\
\hline Ethylbenzene & 30 & 100 \\
\hline Toluene & 10 & 50 \\
\hline Xylene & 15 & 25 \\
\hline Acenaphthene & - & - \\
\hline Anthracene & 10 & 100 \\
\hline Benz[a]anthracene & 10 & 100 \\
\hline Benzo[a]pyrene & 5 & 10 \\
\hline Benzo[b]fluoranthrene & 10 & 100 \\
\hline Benzo[k]fluoranthrene & 10 & 100 \\
\hline Benzoperylene & 5 & 10 \\
\hline Chrysene & 5 & 50 \\
\hline Dibenzo $[\mathrm{a}, \mathrm{h}]$ anthracene * & - & - \\
\hline Fluoranthene & 10 & 100 \\
\hline Indeno[1,2,3-cd]pyrene & 5 & 50 \\
\hline Naphthalene & 5 & 50 \\
\hline Phenanthrene & 5 & 50 \\
\hline Pyrene & 10 & 100 \\
\hline$\Sigma$ PAHs & 25 & 150 \\
\hline Arsenic & 25 & 50 \\
\hline Cadmium & 5 & 10 \\
\hline Total Chromium & 300 & 600 \\
\hline Hexavalent Chromium & 10 & 20 \\
\hline Copper & 250 & 500 \\
\hline Iron & - & - \\
\hline Manganese & 2000 & 4000 \\
\hline Mercury & 4 & 10 \\
\hline Nickel & 200 & 500 \\
\hline Lead & 250 & 1000 \\
\hline Zink & 250 & 1000 \\
\hline
\end{tabular}

${ }^{*}$ N.A. - no data available.

Table 2 illustrates the average concentration levels identified in soil for all investigated contaminants of concern, number of replicates $(\mathrm{N})$, and the range and standard deviation (SD). The last mentioned parameter was derived by applying the equation from Microsoft Office Excel 2007. 
Table 2. Basic statistics for the soil data.

\begin{tabular}{cccccc}
\hline Variable (Congener) & Formula & $\mathbf{N}$ & $\begin{array}{c}\text { Concentrations } \\
\text { in Soil-Range } \\
\text { (mg/kg } \mathbf{d . w .}\end{array}$ & SD & $\begin{array}{c}\text { Concentration in } \\
\text { Soil-Average } \\
\text { (mg/kg d.w.) }\end{array}$ \\
\hline Benzene & $\mathrm{C} 6 \mathrm{H} 6$ & 8 & $0.280-0.780$ & 0.18 & 0.543 \\
Ethylbenzene & $\mathrm{C} 8 \mathrm{H} 10$ & 8 & $0.130-0.430$ & 0.09 & 0.24 \\
Toluene & $\mathrm{C} 6 \mathrm{H} 5-\mathrm{CH} 3$ & 8 & $0.280-0.857$ & 0.21 & 0.537 \\
Xylene & $\mathrm{C} 8 \mathrm{H} 10$ & 8 & $0.210-3.33$ & 0.95 & 1.82 \\
Acenaphthene & $\mathrm{C} 12 \mathrm{H} 10$ & 8 & $0.011-0.080$ & 0.02 & 0.036 \\
Anthracene & $\mathrm{C} 14 \mathrm{H} 10$ & 8 & $0.001-0.027$ & 0.01 & 0.008 \\
Benz[a]anthracene & $\mathrm{C} 18 \mathrm{H} 12$ & 8 & $0.378-0.758$ & 0.13 & 0.598 \\
Benzo[a]pyrene & $\mathrm{C} 20 \mathrm{H} 12$ & 8 & $0.103-0.378$ & 0.11 & 0.214 \\
Benzo[b]fluoranthrene & $\mathrm{C} 20 \mathrm{H} 12$ & 8 & $0.280-0.675$ & 0.13 & 0.434 \\
Benzo[k]fluoranthrene & $\mathrm{C} 20 \mathrm{H} 12$ & 8 & $0.001-0.066$ & 0.02 & 0.042 \\
Benzoperylene & $\mathrm{C} 22 \mathrm{H} 12$ & 8 & $0.052-0.098$ & 0.02 & 0.078 \\
Chrysene & $\mathrm{C} 18 \mathrm{H} 22$ & 8 & $0.823-1.430$ & 0.20 & 0.982 \\
Dibenzo [a,h] anthracene & $\mathrm{C} 22 \mathrm{H} 14$ & 8 & $0.056-0.445$ & 0.13 & 0.255 \\
Fluoranthene & $\mathrm{C} 16 \mathrm{H} 10$ & 8 & $0.012-0.370$ & 0.11 & 0.156 \\
Indeno[1,2,3-cd]pyrene & $\mathrm{C} 22 \mathrm{H} 12$ & 8 & $0.075-0.210$ & 0.04 & 0.125 \\
Naphthalene & $\mathrm{C} 10 \mathrm{H} 8$ & 8 & $0.010-0.091$ & 0.03 & 0.06 \\
Phenanthrene & $\mathrm{C} 14 \mathrm{H} 10$ & 8 & $0.373-0.971$ & 0.23 & 0.717 \\
Pyrene & $\mathrm{C} 16 \mathrm{H} 10$ & 8 & $0.389-1.104$ & 0.24 & 0.775 \\
Arsenic & $\mathrm{As}$ & 8 & $3.4-7.43$ & 1.32 & 5 \\
Cadmium & $\mathrm{Cd}$ & 8 & $0.56-1.43$ & 0.30 & 0.9 \\
Total Chromium & $\mathrm{Cr}$ & 8 & $43.22-0.15$ & 9.50 & 55.3 \\
Hexavalent Chromium & $\mathrm{CrVI}$ & 8 & $0.055-0.130$ & 0.02 & 0.099 \\
Copper & $\mathrm{Cu}$ & 8 & $21.60-60.20$ & 14.03 & 35.63 \\
Iron & $\mathrm{Fe}$ & 8 & $0.334-3.900$ & 1.11 & 2.684 \\
Manganese & $\mathrm{Mn}$ & 8 & $456.45-789.68$ & 103.83 & 673.27 \\
Mercury & $\mathrm{Hg}$ & 8 & $0.016-0.356$ & 0.11 & 0.214 \\
Nickel & $\mathrm{Ni}$ & 8 & $21.23-34.15$ & 5.02 & 27.53 \\
Lead & $\mathrm{Pb}$ & 8 & $39.01-66.31$ & 10.44 & 53.91 \\
Zink & $\mathrm{Zn}$ & 8 & $121.52-178.91$ & 30.91 & 155.98 \\
\hline & & & & &
\end{tabular}

The land use for the present study is recreational, regarding a recreation area (not an ensconced playground) near a school (so, frequented by children). Considering the thresholds from regulation in force in Romania for the investigated contaminants (Table 1), the results show that the average concentrations of contaminants of concern did not exceed the existing threshold values, except benzene, which exceeded the alert threshold (Table 2). In the case of $\Sigma$ PAHs, the determined concentration in soil was below the reference values settled by the Romanian regulation: it was identified as $4.85 \mathrm{mg} / \mathrm{kg}$ d.w. (the warning level is $25 \mathrm{mg} / \mathrm{kg}_{\text {d.w, }}$ and the intervention level is $150 \mathrm{mg} / \mathrm{kg}_{\text {d.w. }}$ for less sensitive land use). According to MO 756/1997 [45], when the concentrations of one or more soil pollutants exceed the alert thresholds, but lie below the intervention threshold for a proper land use, there is a potential impact on the soil. In these situations, the competent authorities take special measures to prevent further pollution of the soil and require additional monitoring of potential sources of contamination. Consequently, the next step in the framework of the developed research work was to assess risks for human health from soil contaminated with the previously-defined contaminants of concern.

\subsection{Carcinogenic Risk Assessment for an Oil-Contaminated Site}

The chemical analysis of the crude oil-contaminated site included different groups of contaminants: PAHs, BTEX compounds, and heavy metals. Among the 16 PAHs identified in the soil, 11 chemicals were considered for the assessment of the carcinogenic risk. Concerning the BTEX group of contaminants, ethylbenzene and benzene were the main contaminants of concern, while for heavy metals group, five metals were taken into account. These choices were made based on the information provided by the US EPA, suggesting that their toxicological profile is recognized as carcinogenic for humans (Table 3). 
Table 3. Non-carcinogenic and carcinogenic compounds determined in the investigated soil.

\begin{tabular}{cc}
\hline Noncarcinogenic Compounds & Carcinogenic Compounds \\
\hline Toluene & Benzene \\
Xylene & Ethylbenzene \\
Acenaphtene & Anthracene \\
Anthracene & Benz [a] anthracene \\
Benzoperylene & Benzo [a] pyrene \\
Fluorene & Benzo [b] fluoranthrene \\
Naphthalene & Benzo [k] fluoranthrene \\
Total Chromium $(\mathrm{Cr})$ & Crysene \\
Copper & Dibenzo [a,h] anthracene \\
Iron & Indeno [1,2,3-cd] pyrene \\
Manganese & Fluoranthene \\
Mercury & Phenanthrene \\
Zink & Pyrene \\
& Arsenic (As) \\
& Cadmium \\
& Hexavalent Chromium (CrVI) \\
& Nickel (Ni) \\
& Lead (Pb) \\
\hline
\end{tabular}

In order to determine the cancer risk, information about toxicity, human exposure pathways, duration, and frequency of exposure and other parameters should be known. The US EPA establishes a parameter for each carcinogenic compound, which is called as the slope factor, which quantitatively defines the relationship between dose and response. This represents an estimated value for toxicity [44]. Thus, in order to calculate risk of developing cancer, several parameters specific to each compound were considered: oral slope factor or inhalation potency factor, the daily intake (calculated based on concentration of each chemical), the frequency and the duration of exposure, etc. [49]. These parameters were considered in the US EPA equations [50]. Across the present research study, the cancer risk, for both children and adults, was assessed considering the following equations:

$$
\text { CancerRisk }=I(\text { Dose }) \times S F
$$

where, $I$ is the chronic daily intake (dose) $\left(\mathrm{mg} / \mathrm{kg} /\right.$ day) and $S F$ is the slope factor $(\mathrm{mg} / \mathrm{kg} / \text { day })^{-1}$.

In case the risk is arising from different contaminants, the total risk is calculated as the sum of the risks generated by each pollutant for each exposure pathway:

$$
\text { Risk }=\sum \text { Risk }_{i}
$$

where Risk $_{i}$ is the estimated risk for each substance.

The pathways of human exposure analyzed in the present study were soil ingestion and dermal contact, according to the existing exposure scenario (recreational). Estimated doses were calculated by the equations below:

- Ingestion of chemicals in soils:

$$
\text { Dose }_{s i}=[C S \times C F \times I R \times F I / B W] \times[E F \times E D / A T]
$$

- Exposure through dermal contact:

$$
\text { Dose }_{d c}=[C S \times C F \times S A \times A F \times A B S \times E F \times E D] /[B W \times A T]
$$

For the calculation of the exposure through soil ingestion (Dose $\left.e_{s i}\right)$ and dermal contact $\left(\right.$ Dose $\left._{d c}\right)$ the following parameters were used: the chemical concentration in soil (CS in $\mathrm{mg} / \mathrm{kg}$ ), the conversion 
factor $\left(C F=10^{-6} \mathrm{~kg} / \mathrm{mg}\right)$, the ingestion rate $(I R, \mathrm{mg}$ soil/day), the fraction ingested from the contaminated source ( $F I$, unitless), the body weight ( $B W$ in $\mathrm{kg}$ ), the exposure frequency ( $E F$ in events/year), the exposure duration ( $E D$ in years), the average time ( $A T$ in days), the skin surface area available for contact ( $S A$ in $\mathrm{cm}^{2}$ /event), the soil to skin adherence factor $\left(A F\right.$ in $\left.\mathrm{mg} / \mathrm{cm}^{2}\right)$, and the absorption factor ( $A B S$, unitless).

Table 4 illustrates the known absorption factors (ABS) related to the investigated chemicals in soil, while Table 5 presents the cancer slope factors (CSF) that were used in the framework of the study in order to estimate the risk of cancer associated with exposure to the investigated carcinogenic or potentially-carcinogenic substances.

Table 4. Absorption factors used for the assessment of dermal contact exposure.

\begin{tabular}{cc}
\hline Substance & Absorption Factors (-) \\
\hline Benzene & $8.00 \times 10^{-2}$ \\
Ethylbenzene & $2.00 \times 10^{-1}$ \\
PAHs & $1.30 \times 10^{-1}$ \\
Arsenic & $4.00 \times 10^{-2}$ \\
Cadmium & $1.00 \times 10^{-3}$ \\
Hexavalent Chromium & $1.00 \times 10^{-2}$ \\
Nickel & $4.00 \times 10^{-2}$ \\
\hline
\end{tabular}

Table 5. Cancer slope factors (dermal contact and oral ingestion).

\begin{tabular}{ccc}
\hline Substance & $\begin{array}{c}\text { Cancer Slope Factor } \\
(\mathbf{m g} / \mathbf{k g} / \text { Day })^{-1}\end{array}$ & Reference \\
\hline Benzene & $3.50 \times 10^{-2}$ & US EPA, 2000 [51] \\
Ethylbenzene & $1.10 \times 10^{-2}$ & NJDEP, 2009 [52] \\
Anthracene & $2.30 \times 10^{-1}$ & HC2, 2007 [29] \\
Benz[a]anthracene & $1.20 \times 100$ & US EPA, 2003 [53] \\
Benzo[a]pyrene & $1.20 \times 10$ & US EPA, 2003 [53] \\
Benzo[b]fluoranthrene & $1.20 \times 10^{+0}$ & US EPA, 2003 [53] \\
Benzo[k]fluoranthrene & $1.20 \times 10^{+0}$ & US EPA, 2003 [53] \\
Benzoperylen & $2.30 \times 10^{-2}$ & HC2, 2007 [29] \\
Crysene & $1.20 \times 10^{-1}$ & US EPA, 2003 [53] \\
Dibenzo [a,h] anthracene & $4.10 \times 10^{+0}$ & US EPA, 2003 [53] \\
Fluoranthene & $2.30 \times 10^{-2}$ & HC2, 2007 [29] \\
Indeno[1,2,3-cd]pyrene & $1.20 \times 10^{+0}$ & US EPA, 2003 [53] \\
Phenanthrene & $2.30 \times 10^{-3}$ & HC2, 2007 [29] \\
Arsenic & $1.50 \times 100$ & US EPA, 2003 [53] \\
Cadmium & $1.50 \times 10$ & US EPA, 2003 [53] \\
Hexavalent Chromium & $4.20 \times 10^{-1}$ & OEHHA, 2009 [54] \\
Nickel & $9.10 \times 10^{-1}$ & US EPA, 2003 [53] \\
Lead & $8.50 \times 10^{-3}$ & US EPA, 2003 [53] \\
\hline
\end{tabular}

With the aim of assessing exposure through dermal contact and soil ingestion, the specific parameters presented in Table 6 are used. The body weight for children was $32 \mathrm{~kg}$ while, for adults, it was $70 \mathrm{~kg}$. Even if, generally, the average time that is taken into account is 2560 days for children (7 years) and 25,600 days for adults (70 years), the exposure duration for the considered scenario in the present study was five years for children and 21 years for adults. 
Table 6. Parameters used for the exposure assessment.

\begin{tabular}{cccc}
\hline & \multicolumn{3}{c}{ Dermal Contact } \\
\cline { 2 - 4 } & $\begin{array}{c}\text { SA-Skin Surface Area } \\
\left(\mathbf{c m}^{2} / \text { Event) }\right.\end{array}$ & $\begin{array}{c}\text { ED-Exposure Duration } \\
\text { (Days) }\end{array}$ & $\begin{array}{c}\text { EF-Exposure Frequency } \\
\text { (Days/Year) }\end{array}$ \\
\hline Children & $5.14 \times 10^{3}$ & $1.82 \times 10^{3}$ & $1.50 \times 10^{1}$ \\
Adults & $9.11 \times 10^{3}$ & $7.66 \times 10^{3}$ & $3.00 \times 10^{1}$ \\
& & Soil Ingestion & \\
\cline { 2 - 4 } & FI-Fraction Ingested from & IRs-Soil Ingestion Rate & EF-Exposure Frequency \\
(mg/Day) & (Days/Year) \\
\hline Children & Contaminated Soil (-) & $1.50 \times 10^{2}$ & $9.00 \times 10^{1}$ \\
Adults & $1.00 \times 10^{-1}$ & $1.00 \times 10^{2}$ & $1.20 \times 10^{2}$ \\
\hline
\end{tabular}

Using RECOLAND, the total carcinogenic risk to an individual from oil contaminated site was assessed. As previously mentioned, the method used for the assessment of risk is based on dose-effect relationships. The average carcinogenic risk for the investigated area was calculated as $1.07 \times 10^{-5}$ for children and $6.89 \times 10^{-6}$ for adults. These results exceed the acceptable risk of $10^{-6}$ (Figure 3).

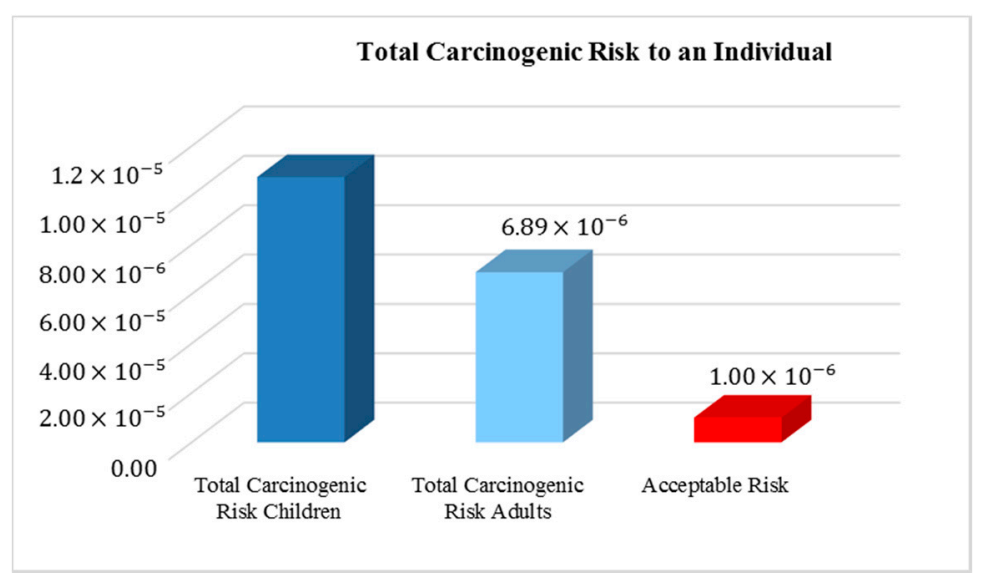

Figure 3. Total carcinogenic risk from crude oil contamination soil in the investigated area.

The carcinogenic risks calculated for each individual compound are illustrated in Figure 4. By examining the risks of the individual compounds, it could be assessed which is/are the contaminant/s that is/are leading to an unacceptable risk in the investigated area. Additionally, the obtained results were compared with the acceptable risk $\left(10^{-6}\right)$ suggested by the World Health Organization for every single contaminant. As shown in the Figure 4, it could be noticed that, although attention is mainly focused on PAHs and MAHs when soil is contaminated by oil spills, arsenic and nickel contamination should not be neglected (Figure 4).

Furthermore, the percentage contribution to the assessed total carcinogenic risk to individuals from heavy metals is significant (95\%) compared to the other groups of chemicals (Figure 5). The results show that, even if metals are not the main concern related to soil contamination with petroleum products, they might contribute significantly to human health risk. Even if there is no certainty that heavy soil contamination is due to the crude oil contamination, the achieved results are in accordance with the results obtained by other authors that showed the importance of soil contamination with heavy metals by oil spills [55-58]. For instance, Asia et al. [59] showed that exploration and production activities introduced a large amount of heavy metals into the soil and groundwater where such activities are carried out. This study suggested pollution by heavy metals (lead, copper, chromium, iron, nickel, and zinc) across petroleum exploration and production operations. Heavy metal contamination of 
soil by crude oil pollution has been reported by other studies as well $[57,60,61]$. Moreover, pollution with crude oil has a negative impact not only on soil characteristics, but could also increase the heavy metal content of vegetation growing on the impacted land, as shown by Bada and Olarinre in 2012 [62]. The obtained results are also confirmed by other authors that have demonstrated that crude oil contamination can lead to gradual heavy metal build-up in the soil with negative consequences on crops from such soils [63].

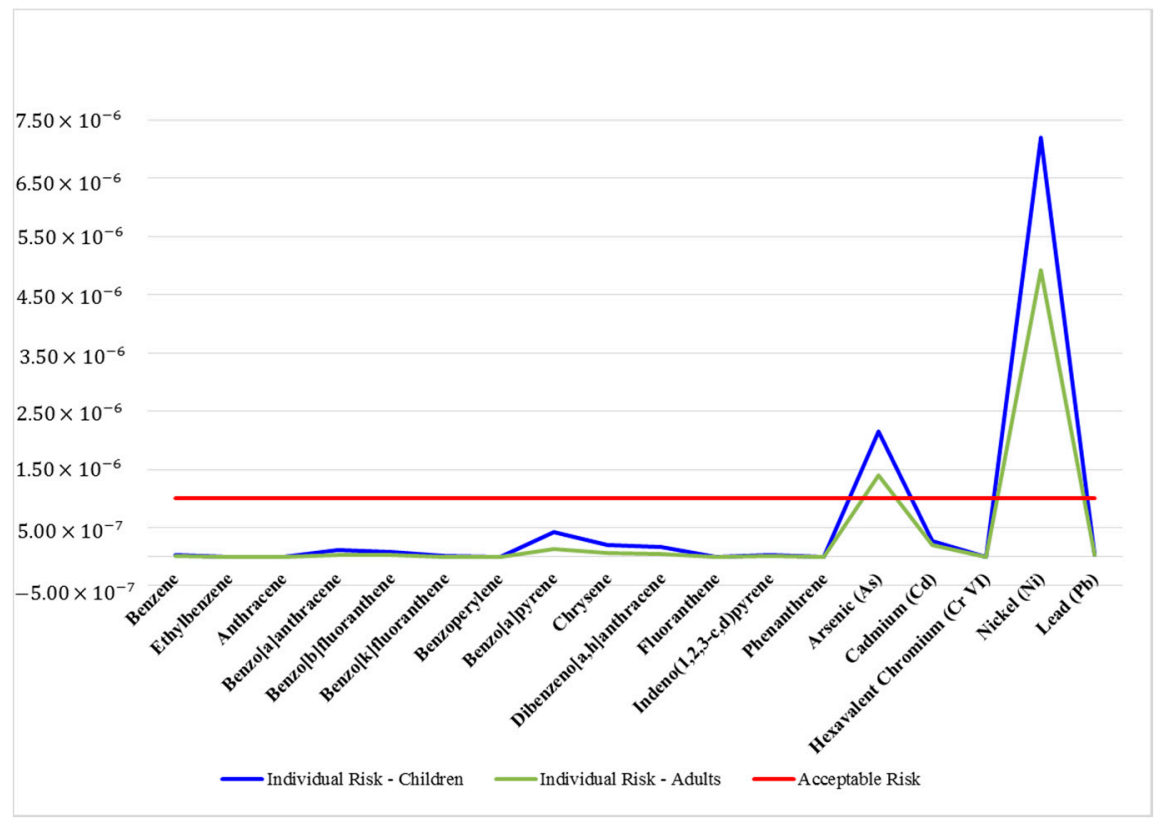

Figure 4. Carcinogenic risks posed by individual contaminants for the contaminated site concerned.

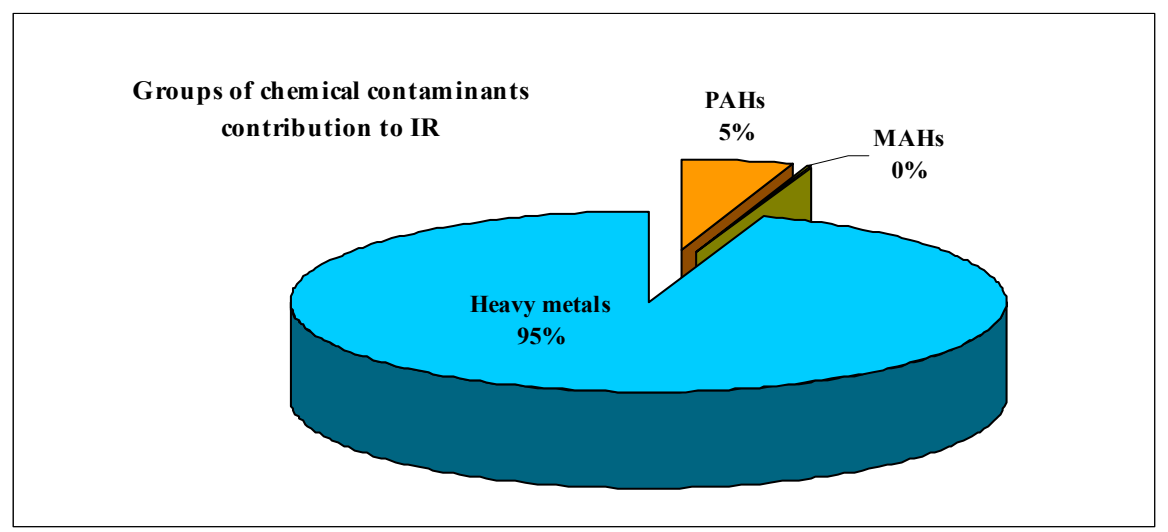

Figure 5. Carcinogenic risks posed by the contaminant groups of PAHs, MAHs, and heavy metals for the contaminated site concerned.

The present study underlines the necessity of carrying out remediation works of the contaminated site simultaneously with the health risk assessment studies based on the risk-based approach. The obtained results for the investigated site should involve decontamination of soil by taking into account the most significant contaminants causing higher risk. On the other hand, further research on heavy metal contamination of soils due to the crude oil pollution is needed as there is a difficulty in distinguishing between historical contamination with heavy metals resulting from the industrial activities (other than petroleum industry) and heavy metal contamination of the soil due oil spills (in case of the same contaminated site). Moreover, within the present study it was 
demonstrated that the analytical tools are a good choice in order to facilitate decision-making in facing environmental challenges.

\section{Summary of Findings}

Considering the achieved results in the framework of the present study, some important considerations may be contemplated:

- RECOLAND quantifies the effects of exposure to soil pollution in terms of carcinogenic risks to humans.

- The assessed high carcinogenic risk to individuals from heavy metals in soil compared to the other groups of chemicals suggested that more research should be conducted in this area (As and $\mathrm{Ni}$ concentrations in soil revealed unacceptable risks to humans).

- Results illustrated in the present paper are supporting the improvement of our capacity for representing, understanding, predicting or managing the behavior of environmental systems at the practical scales.

- This kind of analytical instrument (RECOLAND) may be a good choice in order to facilitate decision-making processes when faced with environmental challenges. In this way, responsible authorities can easily simulate 'what if' scenarios to find the best solution to problems, such as soil pollution.

- The RECOLAND tool could be a valid instrument for the analysis of soils when characterizing, remediating, and monitoring contaminated soil sites.

- Such an operational tool may be useful for defining mitigation measures and for anticipating their qualitative and quantitative effects on soil quality.

- Further studies will be conducted to keep testing the software, but also in order to extend it to other kinds of contaminants that could arise in soil within anthropogenic activities.

\section{Conclusions}

The study developed the assessment of human health risk caused by exposure to carcinogenic PAHs, MAHs, and heavy metals existing in a soil contaminated as a consequence of crude oil pollution with a risk analysis software package (RECOLAND v1.0). Related to the risk determination, the equations indicated by the US EPA considering two main age categories (children and adults) were used. Results showed that the mean of the estimated cancer risk is about $1.07 \times 10^{-5}$ for children and $6.89 \times 10^{-6}$ for adults. Thus, the assessed individual risk from the oil contaminated site is higher than the acceptable value recommended by the WHO $\left(1 \times 10^{-6}\right)$. The study suggested that oil contamination of the soil could be a significant contributor for the higher level of risk.

The results indicated that it is necessary to find an optimal solution for decontaminating the investigated soil to minimize the health risks. The risk estimation process proposed and illustrated in the present study are aimed to show an effective method for decreasing, or even eliminating, the impact of the contaminated site on human and environmental health. By using this risk-based approach, it was shown that some heavy metals might contribute significantly to human health risk in the soils contaminated by petroleum products, even if they are generally not the main concern for such sites. Therefore, future developments should be focused on the implementation of continuous monitoring of heavy metals in the soil when oil spills occur.

As soil pollution is an important environmental issue worldwide, how to manage the contaminated land problem and protect human health is a great challenge for the decision factors that must manage these kinds of aspects. For that reason, the existence of environmental tools, such as RECOLAND, that could be applied for different areas, in different countries, in order to assess risks on humans from contaminated sites is needed. It is becoming possible in this way to transfer knowledge from researchers to decision-makers. 
Acknowledgments: The work was supported by the PNII-RU-TE2014-4-2348/REMPET project, contract No. 354/01.10.2015, SOP IEC POSCCE-A2-O2.1.2.-2009-2, RECOLAND ID519, SMIS-CSNR: 11982, contract No. 182/18.06.2010, and the Erasmus + Programme, EnvyJobs project, contract No. 2015-1-RO01-KA203-015089.

Author Contributions: Diana Mariana Cocârţă conducted the experimental activities for the measurement of the concentrations with regard to the PAHs, BTEX, and heavy metals in soil; established the paper content; and coordinated the activities for reaching the proposed objectives of this study. Mihaela Alexandra Stoian contributed to the bibliographical study of the human health risk method and its different applications; prepared the draft manuscript of the paper; and contributed in writing the paper. Aykan Karademir analyzed the data on which the main conclusions of the present work are based, and participated in writing the paper.

Conflicts of Interest: The authors declare no conflict of interest. The founding sponsors had no role in the design of the study; in the collection, analyses, or interpretation of data; in the writing of the manuscript, and in the decision to publish the results.

\section{References}

1. Albuquerque, M.T.D.; Gerassis, S.; Sierra, C.; Taboada, J.; Martin, J.E.; Antunes, I.M.H.R.; Gallego, J.R. Developing a new Bayesian Risk Index for risk evaluation of soil contamination. Sci. Total Environ. 2017, 603-604, 167-177. [CrossRef] [PubMed]

2. Aziz, S.Q.; Maulood, Y.I. Contamination valuation of soil and groundwater source at anaerobic municipal solid waste landfill site. Environ. Monit. Assess. 2015, 187, 755. [CrossRef] [PubMed]

3. Ding, M.; Chen, Q.; Xiao, X.; Xin, L.; Zhang, G.; Li, L. Variation in cropping intensity in northern China from 1982 to 2012 based on GIMMS-NDVI data. Sustainability 2016, 8. [CrossRef]

4. Rizzardini, C.B.; Goi, D. Sustainability of domestic sewage sludge disposal. Sustainability 2014, 6, $2424-2434$. [CrossRef]

5. Trulli, E.; Morosini, C.; Rada, E.C.; Torretta, V. Remediation in situ of hydrocarbons by combined treatment in a contaminated alluvial soil due to an accidental spill of LNAPL. Sustainability 2016, 8. [CrossRef]

6. EEA (European Environment Agency). Data and Maps EEA, Progress in Management of Contaminated Sites. Available online: http:/ / www.eea.europa.eu (accessed on 1 December 2016).

7. EC (European Commission, Science). Science for Environment Policy In-Depth, Report: Soil Contamination: Impacts on Human Health; Report Produced for the European Commission DG Environment; European Commission: Brussels, Belgium, 2013. Available online: http:/ / ec.europa.eu/environment/integration/ research/newsalert/pdf/IR5_en.pdf (accessed on 23 May 2017).

8. Marinescu, M.; Toti, M.; Tanase, V.; Carabulea, V.; Plopeanu, G.; Calciu, I. An assessment of the effects of crude oil pollution on soil properties. Ann. Food Sci. Technol. 2010, 11, 94-99.

9. Khayati, G.; Barati, M. Bioremediation of Petroleum Hydrocarbon Contaminated Soil: Optimization Strategy Using Taguchi Design of Experimental (DOE). Methodol. Environ. Process. 2017, 4, 451-461. [CrossRef]

10. Adebiyi, F.M.; Oluyemi, E.A.; Adeyemi, A.F.; Akande, A.A.; Ajayi, O.S. A measurement of selected polycyclic aromatic hydrocarbons in petroleum product contaminated soils using a gas chromatograph. Pet. Sci. Technol. 2015, 33, 62-71. [CrossRef]

11. Pinedo, J.; Ibáñez, R.; Lijzen, J.P.A.; Irabien, T. Assessment of soil pollution based on total petroleum hydrocarbons and individual oil substances. J. Environ. Manag. 2013, 130, 72-79. [CrossRef] [PubMed]

12. Cocârţă, D.; Oprea, I.A.; Ragazzi, M.; Andreottola, G.; Ziglio, G.; Badea, A.; Apostol, T. Different technologies for the treatment of PAH contaminated sediments and consequences on human health individual risk. WIT Trans. Ecol. Environ. 2008, 110, 53-60.

13. Cocârţă, D.M.; Rada, E.C.; Ragazzi, M.; Badea, A.; Apostol, T. A contribution for a correct vision of health impact from municipal solid waste treatments. Environ. Technol. 2009, 30,963-968. [CrossRef] [PubMed]

14. Cocârţă, D.M.; Neamţu, S.; Deac, A.R. Carcinogenic risk evaluation for human health risk assessment from soils contaminated with heavy metals. Int. J. Environ. Sci. Technol. 2016, 13, 2025-2036. [CrossRef]

15. Dumitrescu, C.; Cocârţă, D.M.; Resetar-Deac, A.M.; Badea, A.; Biolan, M. Human health Risk Assessment of contaminated sites with carcinogenic pollutants. Present Environ. Sustain. Dev. 2012. Available online: http:/ / pesd.ro/articole/nr.6/2/35HHRAOCSWCP15102012415428.pdf (accessed on 1 June 2017).

16. Fernández-Caliani, J.C. Risk-based assessment of multimetallic soil pollution in the industrialized peri-urban area of Huelva, Spain. Environ. Geochem. Health 2011, 34, 123-139. [CrossRef] [PubMed] 
17. Moraru, R.I.; Babut, G.B.; Cioca, L.I. Rationale and criteria development for risk assessment tool selection in work environments. Environ. Eng. Manag. J. 2014, 13, 1371-1376.

18. Ştefănescu, L.; Robu, B.M.; Ozunu, A. Integrated approach of environmental impact and risk assessment of Rosia Montana Mining Area, Romania. Environ. Sci. Pollut. Res. 2013, 20, 7719-7727. [CrossRef] [PubMed]

19. Walden, T. Risk Assessment in Soil Pollution: Comparison Study. Rev. Environ. Sci. Biotechnol. 2005, 4, 87-113. [CrossRef]

20. Fallah, M.; Shabanpor, M.; Ebrahimi, S. Evaluation of petroleum impacts on some properties of loamy sand soil with the main focus on hydraulic properties. Environ. Earth Sci. 2015, 74, 4751-4762. [CrossRef]

21. Kuang, S.; Wu, Z.; Zhao, L. Accumulation and risk assessment of polycyclic aromatic hydrocarbons (PAHs) in soils around oil sludge in Zhongyuan oil field, China. Environ. Earth Sci. 2011, 64, 1353-1362. [CrossRef]

22. Rezaei, A.; Shayestehfar, M.; Tavakoli Mohammadi, M.R. Assessment of the metals contamination and their grading by SAW method: A case study in Sarcheshmeh copper complex, Kerman. Iran. Environ. Earth Sci. 2015, 74, 3191-3205. [CrossRef]

23. Wang, L.; Xu, X.; Lu, X. Composition, source and potential risk of polycyclic aromatic hydrocarbons (PAHs) in vegetable soil from the suburbs of Xianyang City, Northwest China: A case study. Environ. Earth Sci. 2016, 75. [CrossRef]

24. MEWF Ministry of Environment, Waters and Forests. National Strategy for the Management of Contaminated Sites, Romania. 2015. Available online: http:/ / www.mmediu.ro/beta/wp-content/uploads/2013/10/201310-29_strategie.pdf (accessed on 31 May 2017).

25. Swartjes, F.A. Dealing with Contaminated Sites from Theory towards Practical Application; Springer: Bilthoven, The Netherlands, 2011; Part I, Chapter 1.

26. Valentín, L.; Nousiainen, A.; Mikkonen, A. Introduction to Organic Contaminants in Soil: Concepts and Risks, Chapter 1 in Emerging Organic Contaminants in Sludges. In The Handbook of Environmental Chemistry; Vicent, T., Caminal, G., Eljarrat, E., Barceló, D., Eds.; Springer: Berlin/Heidelberg, Germany, 2013; Volume 24.

27. Agency for Toxic Substances and Disease Registry (ATSDR). Toxicological Profile for Polycyclic Aromatic Hydrocarbons (PAHs). 2015. Available online: https:/ / www.atsdr.cdc.gov / toxprofiles /TP.asp?id=122\&tid=25 (accessed on 15 January 2016).

28. International Agency for Research on Cancer (IARC). Some Non-Heterocyclic Polycyclic Aromatic Hydrocarbons and Some Related Exposures; Monographs on the Evaluation of Carcinogenic Risks to Humans; International Agency for Research on Cancer: Lyon, France, 2010; Volume 92.

29. Health Canada. Federal Contaminated Site Risk Assessment in Canada Part I: Guidance on Human Health Preliminary Quantitative Risk Assessment, version 2.0; Health Canada: Ottawa, ON, Canada, 2007.

30. International Organization for Standardization. SR ISO 13877:1999 Soil Quality_Determination of Polycyclic Aromatic Hydrocarbons (PAH) by Gas Chromatography (GC) and High Performance Liquid Chromatography (HPLC); International Organization for Standardization: Geneva, Switzerland, 1999.

31. Lynam, K.G.; Smith, D. Polycyclic Aromatic Hydrocarbon Analysis Using an Agilent JEW DB-5ms Ultra Inert Capillary GC Column; Agilent Application 5989-9181EN; Agilent Technologies Inc.: Santa Clara, CA, USA, 2008.

32. Szelewski, M. Synchronous SIM/Scan Low-Level PAH Analysis Using the Agilent Technologies 6890/5975 Inert GC/MSD; Agilent Application 5989-4184EN; Agilent Technologies Inc.: Santa Clara, CA, USA, 2009.

33. International Organization for Standardization. ISO 22155:2011, Soil Quality-Gas Chromatographic Determination of Volatile Aromatic and Halogenated Hydrocarbons and Selected Ethers-Static Headspace Method; International Organization for Standardization: Geneva, Switzerland, 2011.

34. United States Environmental Protection Agency (EPA). EPA 8260B:1996, SW-846 Test Method 8260B: Volatile Organic Compounds by Gas Chromatography/Mass Spectrometry (GC/MS); United States Environmental Protection Agency: Washington, DC, USA, 1996.

35. International Organization for Standardization. SR ISO 11047:1999, Soil Quality—Determination of Cadmium, Chromium, Cobalt, Copper, Lead, Manganese, Nickel and Zinc-Flame and Electrothermal Atomic Absorption Spectrometric Methods; International Organization for Standardization: Geneva, Switzerland, 1999.

36. International Organization for Standardization. ISO 20280:2007, Soil Quality-Determination of Arsenic, Antimony and Selenium in Aqua Regia Soil Extracts with Electrothermal or Hydride-Generation Atomic Absorption Spectrometry; International Organization for Standardization: Geneva, Switzerland, 2007. 
37. United States Environmental Protection Agency (US EPA). Hurricane Sandy Cleanup: Oil Contamination in Soil, December 2012; United States Environmental Protection Agency: Washington, DC, USA, 2012.

38. Boda, D.M. Study on the impact assessment and the soil pollution risk produced by the specific activities of metallurgical industry. In Proceedings of the A X-a Conferinţă Naţională Multidisciplinară-Cu Participare Internaţională, "Profesorul Dorin Pavel—Fondatorul Hidroenergeticii Româneşti", Sebeş, Romania, 3-4 June 2010.

39. Rikken, M.G.J.; Lijzen, J.P.A.; Cornelese, A.A. Evaluation of Model Concepts on Human Exposure: Proposal for Updating the Most Relevant Exposure Routes of CSOIL; National Institute for Public Health and the Environment (RIVM): Bilthoven, The Netherlands, 2001.

40. Swartjes, F.A. Dealing with Contaminated Sites from Theory towards Practical Application; Springer: Bilthoven, The Netherlands, 2011; Part I, Chapter 5.

41. Kim, K.; Jahan, S.A.; Kabir, E.; Brown, R.J.C. A review of airborne polycyclic aromatic hydrocarbons (PAHs) and their human health effects. Environ. Int. 2013, 60, 71-80. [CrossRef] [PubMed]

42. Hua, Y.; Luo, Z.; Cheng, S.; Xiang, R. Health risks of organic contaminated soil in an out-of-service oil refinery site. J. Earth Sci. 2012, 23, 121-128. [CrossRef]

43. Dumitrescu, C.; Cocârţă, D.M.; Badea, A. An integrated modeling approach for risk assessment of heavy metals in soils. Sci. Bull. Ser. D 2012, 74, 217-228.

44. United States Environmental Protection Agency (US EPA). RAIS the Risk Assessment Information System, Glossary of Environmental Restoration Terms; United States Environmental Protection Agency: Washington, DC, USA, 2016.

45. Ministry Order (MO). No. 756 from November 3, 1997 for Approval of Regulation Concerning Environmental Pollution Assessment; Published in Official Monitor No. 303/6 November 1997. Available online: http:/ / biosol.ro/wp-content/uploads/linkuri/ord-756-din-03-11-1997-pentru-aprobareaReglementarii-privind-evaluarea-poluarii-mediului.pdf (accessed on 14 April 2017).

46. Brande, E.; Piet, O.; Lijzen, J. CSOIL 2000: An Exposure Model for Human Risk Assessment of Soil Contamination, A Model Description; RIVM Report 711701054/2007, Ministry of Housing, Spatial Planning and the Environment, within the Framework of Project 711701, Risks in Relation to Soil Quality; National Institute for Public Health and the Environment (RIVM): Bilthoven, The Netherlands, 2007.

47. United States Environmental Protection Agency (US EPA). Risk Assessment Guidance for Superfund, Volume I Human Health Evaluation Manual, Part A; EPA/540/1-89/002; Office of Emergency and Remedial Response: Washington, DC, USA, 1989.

48. United States Environmental Protection Agency (US EPA). Risk Assessment Guidance for Superfund, Volume I Human Health Evaluation Manual, Part B (Development of Risk-based Preliminary Remediation Goals); EPA/540/R-92/003; Office of Emergency and Remedial Response: Washington, DC, USA, 1991.

49. Office of Environmental Health Hazard Assessment (OEHHA). Air Toxics Hot Spots Program Risk Assessment Guideline, The Air Toxics Hot Spots Program Guidance Manual for Preparation of Health Risk Assessments; US EPA: Washington, DC, USA, 2015.

50. Office of Environmental Health Hazard Assessment (OEHHA). Joan E. Denton, Adoption of Unit Risk Value for Naphthalene; US EPA: Washington, DC, USA, 2004.

51. United States Environmental Protection Agency (US EPA). CASRN-71-43-2 Integrated Risk Information System (IRIS); Chemical Assessment Summary; National Center for Environmental Assessment: Washington, DC, USA, 2000.

52. New Jersey Department of Environmental Protection (NJDEP). Toxicity Factors Used to Develop Human Health Basis for DEP Standards; Integrated Risk Information System (IRIS), CAS-100-41-4; New Jersey Department of Environmental Protection: Trenton, NJ, USA, 2009.

53. United States Environmental Protection Agency (US EPA). The Air Toxics Hot Spots Program Guidance Manual for Preparation of Health Risk Assessments; Office of Environmental Health Hazard Assessment California Environmental Protection Agency: Sacramento, CA, USA, 2003.

54. Office of Environmental Health Hazard Assessment (OEHHA). Air Toxics Hot Spots Program Technical Support Document for Cancer Potencies. 2009. Available online: https:/ / oehha.ca.gov/media/CPFs042909.pdf (accessed on 16 March 2017).

55. Chukwujindu, M.A. Iwegbue Assessment of heavy metal speciation in soils impacted with crude oil in the Niger Delta, Nigeria. Chem. Spec. Bioavailab. 2011, 23, 7-15. [CrossRef] 
56. Lima, C.A.; Castro, A.M.; Carmen, C.Z.; Ferreira, L.S.G. Human health risk assessment by exposure to heavy metals in a contaminated soil by oil spill. In Proceedings of the XIII International Conference on Heavy Metals in the Environment (ICHMET), Rio de Janeiro, Brazil, 5-9 June 2005.

57. Mustafa, A.D.; Juahir, H.; Yunus, K.; Amran, M.A.; Hasnam, A.N.C.H.; Azaman, F.; Abidin, I.Z.; Azmee, S.H.; Sulaiman, N.H. Oil spill related heavy metal: A review. Malays. J. Anal. Sci. 2015, 19, 1348-1360.

58. Reza, S.K.; Baruah, U.; Singh, S.K. Soil risk assessment of heavy metal contamination near Oil Refinery area, Northeastern India. Int. J. Agric. Environ. Biotechnol. 2014, 7, 787-795. [CrossRef]

59. Asia, I.O.; Jegede, S.I.; Jegede, D.A.; Ize-Iyamu, O.K.; Akpasubi, E.B. The effects of petroleum exploration and production operations on the heavy metals contents of soil and groundwater in the Niger Delta. Int. J. Phys. Sci. 2007, 2, 271-275.

60. Olufemi, A.G.; Titilayo, E.A.; Tunde, E.O. Evaluation of Total Petroleum Hydrocarbons (TPH) and some related heavy metals in soil and groundwater of Ubeji Settlement, Warri Metropolid, Nigeria. Terr. Aquat. Environ. Toxicol. 2012, 6, 61-65.

61. Richardson, V.P.S.; Herath, G.B.B.; Kalpage, C.S.; Jinadasa, K.B.S.N. Physico-Chemical Characteristic of a Petroleum Contaminated Soil from the Spill site of Jaffna District. In Proceedings of the 6th International Conference on Structural Engineering and Construction Management 2015, Kandy, Sri Lanka, 11-13 December 2015.

62. Bada, B.S.; Olarinre, T.A. Characteristics of Soils and Heavy Metal Content of Vegetation in Oil Spill Impacted Land in Nigeria. In Proceedings of the Annual International Conference on Soils, Sediments, Water and Energy, Amherst, MA, USA, 15-18 October 2012; Volume 17, Article 2.

63. Agbogidi, O.M.; Eurotor, P.G.; Akparobu, S.O.; Nnaji, G.U. Heavy Metals Contents of Maize (Zea mays L.) Grown in Soil Contaminated with crude oil. Int. J. Bot. 2007, 3, 385-389. [CrossRef]

(C) 2017 by the authors. Licensee MDPI, Basel, Switzerland. This article is an open access article distributed under the terms and conditions of the Creative Commons Attribution (CC BY) license (http:// creativecommons.org/licenses/by/4.0/). 